\title{
Sınava Hazırlanan Öğrencilerde Sınav Kaygısı ile Antropometrik Ölçümler Arasındaki İlişkinin İncelenmesi
}

\author{
The Examination of the Relationship Between Test Anxiety and Anthropometric Measurements \\ in Students Preparing for the Exam
}

\author{
Handan Öğretir ${ }^{1}$, Perim F. Türker ${ }^{2}$
}

Geliş tarihi/Received: 08.06.2021 • Kabul tarihi/Accepted: 07.12.2021

\section{ÖZET}

Amaç: Bu çalışma, sınava hazırlanan öğrencilerde sınav kaygısı ile antropometrik ölçümler arasındaki ilişkiyi belirlemek amacıyla yapılmıştır.

Bireyler ve Yöntem: Çalışma, Aralık 2019-Mart 2020 tarihleri arasında Ankara’da bulunan özel bir öğretim kursunda 11. ve 12. sinıflarda öğrenim görmekte olan, 16-18 yaş arası 142 kız, 83 erkek olmak üzere toplam 225 gönüllü lise öğrencisi üzerinde yürütülmüştür. Öğrencilerin kişisel özellikleri, sağlık durumları, beslenme alışkanlıkları bir anket aracılığıyla sorgulanmış ve antropometrik ölçümleri alınmıştır. Sınav kaygısını ölçmek amacıyla Revize Edilmiş Sınav Kaygısı (Revised Test Anxiety Scale-RTA) ölçeği kullanılmıştır.

Bulgular: Çalışmaya katılan öğrencilerin yaş ortalaması $17.38 \pm 0.65$ yıldır. Erkek öğrencilerin RTA ölçeği puan ortalamaları $(41.00 \pm 10.69) \mathrm{kız}$ öğrencilere göre $(46.21 \pm 11.45)$ daha düşük bulunmuştur $(\mathrm{p}<0.05)$. Çalışmaya katılan öğrencilerin yaş, öğrenim durumu, eğitim görülen liseye göre RTA ölçeği puan ortalamaları arasındaki farkın istatistiksel olarak anlamlı olmadığı saptanmıştır (p>0.05). Öğrencilerin vücut ağırlı̆̆ı, boy uzunluğu, bel çevresi ölçümleri ile RTA ölçeği toplam puanları arasında istatistiksel açıdan anlamlı ve negatif yönlü korelasyon bulunmuştur ( $<<0.05)$. Bel/boy oranı ve beden kütle indeksi ölçümleri ile RTA ölçeği puanları arasında korelasyon saptanmamıştır ( $p>0.05)$.

Sonuç: Bu çalışma, sınava hazırlanan kız öğrencilerde kaygı düzeyinin daha fazla olduğunu ve öğrencilerde sınav kaygısının bazı antropometrik ölçümler arasında ilişki olabileceğini göstermiştir. Öğrencilerin kaygı ile başa çıkmaları için etkili yöntemler geliştirilmeli ve doğru beslenme alışkanlıkları edinmeleri sağlanmalıdır.

Anahtar kelimeler: Sinav kaygısı, lise öğrencileri, antropometrik ölçümler

\section{ABSTRACT}

Aim: This study was conducted to determine the relationship between test anxiety and anthropometric measurements in students preparing for the exam.

Subjects and Method: The study was conducted on a total of 225 volunteer students (142 female, 83 male) between the ages of 16-18 who were studying in the 11th and 12th grades in a private educational school in Ankara between December

1. İletişim/Correspondence: Uzman Diyetisyen, Türkiye E-posta: hndnogrtr@gmail.com • 은 https://orcid.org/0000-0003-4526-415X
2. Başkent Üniversitesi Sağlık Bilimleri Fakültesi Beslenme ve Diyetetik Bölümü, Türkiye • • https://orcid.org/0000-0002-4254-3711 
2019-March 2020. Students' personal characteristics, health status, nutritional habits were assessed using a questionnaire and their anthropometric measurements were taken. The Revised Test Anxiety Scale (RTA) was used to measure students' exam anxiety.

Results: The mean age of the students participating in this study was $17.38 \pm 0.65$ years. The RTA mean scores of male students $(41.00 \pm 10.69)$ were lower than female students $(46.21 \pm 11.45)(\mathrm{p}<0.05)$. It was determined that the difference between the mean scores of RTA according to the age, education level, high school education was not statistically significant ( $p>0.05)$. A statistically significant and negative correlation was found between the students' body weight, height, waist circumference and the total scores of RTA $(\mathrm{p}<0.05)$. No correlation was found between the waist/height ratio and body mass index measurements and RTA scores of the students ( $>0.05)$.

Conclusion: This study show that the level of anxiety is higher in females who are preparing for the exam, and that there may be a relationship between some anthropometric measures of test anxiety in students. Effective methods should be developed for students to cope with anxiety and they should be provided with the right nutrition habits.

Keywords: Exam anxiety, high school students, anthropometric measurements

\section{GíRiş}

Adölesan dönem fiziksel, biyokimyasal, ruhsal ve sosyal yönden büyük ölçüde değişikliklerin yaşandığı ve büyümenin hızlı olduğu bir süreçtir. Bu süreçte yeterli ve dengeli beslenmenin sağlanması, önerilen miktarda makro ve mikro besin ögesi alınması büyük önem taşımaktadır (1). Adölesan dönemdeki bireyler, yetişkinlikte uygulayacakları beslenme davranışlarının temelini oluşturabilecek yeme alışkanlıklarını kazanırlar (2). Bebeklik döneminden sonra en hızlı büyümenin yaşandığı süreç adölesan dönemdir. Beslenme yetersizliği zayıflık, bodurluk ve demir eksikliği anemisi gibi fizyolojik durumlara neden olabilmektedir. Besinlerin aşırı tüketimi ve sağlıksız besinlere yönelime bağlı olarak obezite, tip 2 diyabet gibi birçok riskli ve ilerideki yaşamı etkileyebilecek hastalıklar meydana gelebilmektedir (3). Aynı zamanda sağlıklı besinlerin yetersiz tüketimi ve/veya sağlıksız ve işlenmiş besinlerin aşırı tüketiminin adölesanlarda ruh sağlığı sorunları riskini artırabileceği bilinmektedir (4).

Son zamanlarda, adölesanlarda toplam yağ, doymuş yağ, kolesterol, şeker ve sodyumun aşırı alımı söz konudur. Bu şekilde bir beslenme tarzı, büyüme ve gelişmenin hız kazandığı bu dönemde ihtiyaç duyulan diyet posası, vitamin ve minerallerden yoksundur. Ayrıca sedanter yaşam tarzı adölesanlarda obezite riskini artırmaktadır. Özellikle orta ergenlik döneminde (15-18 yaş aralığı) beslenme davranışlarında bozukluklar ve kaygı gibi farklı psikolojik durumlar yüksek prevalansa sahiptir. Beden imajının öneminin artması, sosyal medya ve arkadaş çevresi gibi sosyokültürel faktörler, bu durumun nedenleri arasında gösterilmektedir. Bu dönemde sigara ve alkol kullanımı da görülebilmektedir. Bu tür davranışlar fizyolojik gelişimi önemli ölçüde etkiler niteliktedir (3).

Türkiye'de üniversite sinavlarına hazırlanan öğrenciler büyük bir rekabet içindedirler. Yüksek puan alma hedefiyle yoğun bir tempoyla çalışmak, öğrencilerin bu dönemde çeşitli sorunlarla karşılaşmasına neden olabilmektedir. Bu sorunlardan birisi de sınav kaygısıdır (5). Sınav kaygısı sınavla ilgili durumlarda ortaya çıkan yoğun endişe ve yaşanılan sıkıntılı durumları ifade eder. Genellikle sınavdan önce veya sınav sırasında stres ve endişe yaşamak normal ve hatta belli bir seviyeye kadar yararlı kabul edilir. Bu yarar zihnin soruları çözmeye hazır bir duruma gelmesi olarak düşünülebilir. Ancak, daha yüksek seviyede hissedilen sinav kaygısı öğrenme becerisini ve sinav performansını olumsuz yönde etkileyebilir. Aşırı korku ve gergin olma hali sınavda odaklanmayı zorlaştırır ve birey önceden öğrenilmiş bilgileri hatırlamakta zorlanabilir. Sınav sırasında iyi bilinen bir konu veya sahip olunan bir yetenek, kaygı 
nedeniyle gösterilemeyebilir. Dolayısıyla öğrencinin performansının azalmasına neden olur. Sinav kaygisı yaşayan öğrencilerin yaşamayan öğrencilere göre \%12 daha az performans gösterdikleri bildirilmiştir (6). Beiter et al. (7), 374 öğrencinin katıldığı bir çalışmada, öğrencilerin en önemli kaygılarının akademik performans ve başarılı olma baskısı olduğunu saptamıştır.

Öğrenciler sinav dönemlerinde diğer dönemlere göre dahafazlastresaltındadırlar.Stres;fiziksel, duygusalve zihinsel yönden bireyi olumsuz etkileyebilir. Özellikle öğrencilerde strese bağlı diyare, konstipasyon, iştahta değişim gibifizikselbulgulargözlenebilir.Stres vekaygı durumları öğrencilerin sınav başarısı dışında yeme davranışlarını da etkileyebilmektedir. Bazı bireylerin iştahları artarken bazılarının da azalabilmektedir. İştah artışı ve/veya azalmasına bağlı olarak bireylerin beslenme durumları etkilenmekte, sağlık problemleri artmaktadır. Sınav dönemi, öğrencilerin en iyi akademik ve zihinsel performansı göstermeleri için yeterli ve dengeli beslenmeye ihtiyaçları olduğu bir dönemdir. Aynı zamanda bu dönemde yeme davranışlarındaki değişiklikler sağlıksız beslenme için yüksek riskli bir süreç oluşturabilmektedir. Öğrencilerin bazıları zamanlarının kısıtlı olması ve stres gibi nedenlerle sınav dönemlerinde sağlıklı yeme alışkanlıkları konusunda daha fazla zorluk yaşadıklarını bildirirken bazıları da yeterli ve dengeli beslenme için çaba harcadıklarını bildirmektedir (8).

Adölesan dönemde sınav kaygısının öğrencilerin beslenme durumlarını olumsuz yönde etkilediği düşünüldüğünde bu çalışmada, üniversite sınavına hazırlanan adölesan bireylerin sınav kaygısı düzeyleri ile bazı antropometrik ölçümleri arasındaki ilişkileri belirlemek amaçlanmıştır.

\section{BİREYLER VE YÖNTEM}

\section{Araştırmanın Yeri, Zamanı ve Örneklemi}

Bu çalışma, Aralık 2019-Mart 2020 tarihleri arasında Ankara ilinde bir özel öğretim kursunda 11. ve 12. sınıflarda öğrenim görmekte olan ve üniversite sınavına hazırlanan, çalışmaya katılmayı gönüllü olarak kabul eden, 16-18 yaş aralığındaki öğrenciler üzerinde yürütülmüştür. Araştırmadan alınan verilerin istatistiksel olarak değerlendirilmesi için; vücut ağırlığı ile sınav kaygısı arasındaki korelasyonun literatür incelendiğinde düşük-orta düzeyde bir ilişki gösterdiği görülmüştür (9). Buna dayanarak düşük düzeyde etki büyüklügünü ( $\mathrm{r}=0.141) \% 5$ tip 1 hata olasılığı ve \%85 güç ile ortaya çıkarabilmek için G-Power programı kullanılarak en az 225 öğrenci ile çalışılması uygun görülmüştür. Çalışma için, Başkent Üniversitesi Etik Kurulu'ndan 11/12/2019 tarih ve 19/128 sayılı karar ile onay alınmıştır. Katılımcılara ve ebeveynlerine çalışma hakkında bilgi verildikten sonra çalışmaya gönüllü olarak katılmak isteyen bireyler, ebeveynlerinin izni alındıktan sonra, dahil edilmiş ve katılımcılara "Çocuklarda Yapılacak Araştırmalar için Bilgilendirilmiş Gönüllü Onam Formu” okutulup imzalatılmıştır. Katılımcıların ebeveynlerine ise "Bilgilendirilmiş Gönüllü Onam Formu” okutulup imzalatılmıştır. Çalışmaya dâhil edilen bireylerin tüm bilgileri yüz yüze görüşme tekniği kullanılarak elde edilmiştir.

\section{Araştırmanın Genel Planı}

Çalışmaya katılmayı kabul eden tüm öğrencilere demografik özelliklerinin sorgulandığı anket formu uygulanmıştır. Ailenin gelir durumu beyana dayalı sorgulanmıştır. "Gelir giderden az" ise düşük, "Gelir giderle eşit” ise orta, "Gelir giderden yüksek" ise yüksek olarak kabul edilmiştir. Öğrencilerin antropometrik ölçümleri alınmış ve anket formuna kaydedilmiştir. Bireylerin boy uzunluğu (cm), bel çevresi $(\mathrm{cm})$ ölçümleri esnemeyen mezura ile yapılmıştır. Bireylerin vücut ağırlığı (kg) taşınabilir hassas terazi ile belirlenmiştir. Araştırmaya katılan bireylerin boy uzunluğu ölçülürken katılımcının başı frankort düzlemde, ayakkabısız, ayakları bitişik, topuklar, sırt, omuzlar ve başın arka kısmı duvara değecek şekilde durmasına dikkat edilmiştir. Bel çevresi ölçümü için, ayakların birleşik durumda ve kolların iki yanda olmasina dikkat edilerek en alt kaburga kemiği ile kristailiyak arası orta nokta 
bulunmuş ve çevresi ölçülmüştür (10). Bel/boy oranı bel çevresinin $(\mathrm{cm})$ boy uzunluğuna $(\mathrm{cm})$ bölünmesi ile hesaplanmıştır. Bel çevresi/boy uzunluğu oranının değerlendirilmesinde Ashwell ve Hsieh (11)'in sınıflamasından yararlanılmıştır. Bu sınıflamaya göre $<0.4$ “zayıf/düşük”, 0.4-0.5 “normal”, 0.5-0.6 "hafif kilolu/risk” ve $\geq 0.6$ “obez/yüksek risk” olarak kabul edilmiştir. Vücut ağırlığının (kg) boy uzunluğunun karesine $\left(\mathrm{m}^{2}\right)$ bölünmesi ile beden kütle indeksi (BKI) hesaplanmıştır (BKİ $\left(\mathrm{kg} / \mathrm{m}^{2}\right)$ = Vücut ağırlı̆̆ı (kg) / Boy uzunluğu $\left(\mathrm{m}^{2}\right)$ ). Yaşa göre BKİ değerleri, Dünya Sağlık Örgütü Çok Merkezli Büyüme Referans Çalışması (WHO- MHRS) kriterlerine göre değerlendirilmiştir (12). Bu sinıflamaya göre <3. persentil "çok zayıf”, 3.15. persentil “zaylf”, 15.-85. persentil “normal”, 85.-97. persentil "fazla kilolu” ve $>97$. persentil "obez" olarak kabul edilmiştir.

Revize Edilmiş Sınav Kaygısı Ölçeği: Bireylerin sınav kaygısını ölçmek amacıyla Revize Edilmiş Sınav Kaygısı ölçeği (RTA) uygulanmıştır. Benson ve El-Zahhar (13) tarafından geliştirilmiş olan ölçeğin Türkçe geçerlik ve güvenirliği Akın ve ark. (14) tarafından 2012 yılında yapılmıştır. Revize edilmiş sınav kaygısı ölçeği 20 maddeden ve 4 alt ölçekten (Gerginlik, bedensel belirtiler, endişe, sınavla ilgisiz düşünceler) oluşmaktadır. Ölçekte; (1) Hiçbir zaman, (2) Bazen, (3) Çoğu zaman ve (4) Her zaman şeklinde dört cevap seçeneği vardır. Ters puanlanan madde yoktur ve alınan puan ile sinav kaygısı düzeyi pozitif ilişkilidir. Yüksek puan, yüksek sınav kaygısı düzeyini; düşük puan, düşük sinav kaygısı düzeyini göstermektedir. Ölçekten elde edilen puanlar 20 - 80 arasında değişmektedir $(13,14)$.

\section{Verilerin İstatistiksel Değerlendirmesi}

Verilerin istatistiksel olarak analiz edilmesinde Statistical Package for Social Sciences (SPSS) 24.0 yazılımı kullanılmıştır. Öğrencilerin sosyo-demografik bilgilerinin verileri yüzdelik olarak verilmiştir. Nicel veriler için ortalama, standart sapma, alt ve üst değerler hesaplanmıştır. Nicel değişkenlerin karşılaştırılması için normallik varsayımı incelenmiş olup sonuçlara göre parametrik olmayan testler kullanılmıştır. Analizlerde \%5 hata payı ve \%95 güven aralığı ile çalışılmış ve $\mathrm{p}<0.05$ değeri anlamlı kabul edilmiştir. Öğrencilerin cinsiyetlerine göre antropometrik ölçümlerinin dağılımları için ki-kare testi yapılmıştır. Revize Edilmiş Sınav Kaygısı ölçeği puanları ortalama $(\bar{X})$, standart sapma (SS), alt ve üst değerleri tanımlayıcı istatistikleri ile verilmiştir. Öğrencilerin sosyo-demografik özelliklerine göre RTA ölçeği puan ortalamaları Kruskal-Wallis $H$ ve Mann-Whitney U testi ile değerlendirilmiş, normal dağılmadığı tespit edilen nicel değişkenler arası ilişki incelenirken Spearman korelasyon katsayısı kullanılmıştır.

\section{BULGULAR}

Çalışmaya toplam 225 öğrenci katılmıştır. Öğrencilerin \%36.89’u (83) erkek ve \%63.11’i (142) kız olup, yaş ortalaması $17.38 \pm 0.65$ ylldır. Öğrencilerin çoğunluğunu (\%78.22) 12. sinıfta ve \%76.44'ü devlet lisesinde öğrenimlerine devam etmektedir. Gelir düzeylerini \%73.33’ü orta, \%24'ü yüksek olarak beyan etmiştir. Öğrencilerin \%72.89’u takdir belgesi alarak sınıf geçtiğini ifade etmiştir (Tablo 1).

Çalışmaya katılan erkek öğrencilerin vücut ağırlığı ortalaması $72.69 \pm 14.54 \mathrm{~kg}$, boy uzunluğu ortalaması $179.00 \pm 6.75 \mathrm{~cm}$, bel çevresi ortalaması $80.93 \pm 11.08 \mathrm{~cm}$, bel/boy oranı ortalaması $0.45 \pm 0.06$ ve BKİ ortalaması $22.62 \pm 3.95 \mathrm{~kg} / \mathrm{m}^{2}$ şeklinde bulunmuştur. Kız öğrencilerin ise vücut ağırlığı ortalaması $57.67 \pm 9.37 \mathrm{~kg}$, boy uzunluğu ortalaması $164.58 \pm 5.62 \mathrm{~cm}$, bel çevresi ortalaması $70.45 \pm 8.35 \mathrm{~cm}$, bel/boy oranı ortalaması $0.43 \pm 0.05$ ve BKİ ortalaması $21.26 \pm 3.11 \mathrm{~kg} / \mathrm{m}^{2}$ olarak saptanmıştır (veriler tabloda gösterilmemiştir).

Çalışmadaki öğrencilerin BKİ dağılımları arasında cinsiyetlerine göre istatistiksel olarak anlamlı farkın olduğu belirlenmiştir $(p<0.05)$. Kızlarda normal ağırlıkta olma sıklığı erkeklere göre daha yüksek bulunmuştur. Araştırmaya katılan öğrencilerin cinsiyetlerine göre bel/boy oranları incelendiğinde erkeklerin bel/boy oranlarının kızlara göre daha yüksek olduğu saptanmıştır ( $p<0.05$, Tablo 2). 
Tablo 1. Öğrencilerin sosyo-demografik özelliklerine göre dağılımları

\begin{tabular}{|c|c|c|}
\hline Sosyo-demografik özellikler & $\begin{array}{c}S \\
(n=225)\end{array}$ & $\%$ \\
\hline \multicolumn{3}{|l|}{ Yaş } \\
\hline Yaş (yll), $(\overline{\mathrm{X}} \pm \mathrm{SS})$ & \multicolumn{2}{|c|}{$17.38 \pm 0.65$} \\
\hline 16 yaş & 21 & 9.33 \\
\hline 17 yaş & 96 & 42.67 \\
\hline 18 yaş & 108 & 48.00 \\
\hline \multicolumn{3}{|l|}{ Cinsiyet } \\
\hline Erkek & 83 & 36.89 \\
\hline $\mathrm{K} ı \mathrm{z}$ & 142 & 63.11 \\
\hline \multicolumn{3}{|l|}{ Öğrenim durumu } \\
\hline 11. Sinif & 49 & 21.78 \\
\hline 12. Sinif & 176 & 78.22 \\
\hline \multicolumn{3}{|l|}{ Gelir durumu } \\
\hline Gelir giderden az (Düşük) & 6 & 2.67 \\
\hline Gelir gidere eşit (Orta) & 165 & 73.33 \\
\hline Gelir giderden yüksek (Yüksek) & 54 & 24.00 \\
\hline \multicolumn{3}{|l|}{ Eğitim görülen lise } \\
\hline Devlet lisesi & 172 & 76.44 \\
\hline Özel lise & 53 & 23.56 \\
\hline \multicolumn{3}{|l|}{ Okul başarı durumu } \\
\hline Doğrudan geçen & 13 & 5.78 \\
\hline Teşekkür alan & 48 & 21.33 \\
\hline Takdir alan & 164 & 72.89 \\
\hline
\end{tabular}

Tablo 2. Öğrencilerin cinsiyetlerine göre antropometrik ölçümlerinin dağılımları

\begin{tabular}{|c|c|c|c|c|c|}
\hline \multirow{2}{*}{$\begin{array}{l}\text { Antropometrik } \\
\text { ölçümler }\end{array}$} & \multicolumn{2}{|c|}{$\begin{array}{l}\text { Erkek } \\
(\mathrm{n}=83)\end{array}$} & \multicolumn{2}{|c|}{$\begin{array}{c}\mathrm{Kuz} \\
(\mathrm{n}=142)\end{array}$} & \multirow[t]{2}{*}{$\mathbf{p}$} \\
\hline & $\mathbf{S}$ & $\%$ & S & $\%$ & \\
\hline \multicolumn{6}{|l|}{ BKİ (persentil) } \\
\hline Çok zayıf $(<3$. persentil) & 2 & 2.41 & 5 & 3.65 & \multirow{5}{*}{$0.000 *$} \\
\hline Zaylf (3.-15. persentil) & 11 & 13.25 & 14 & 10.22 & \\
\hline Normal (15.-85. persentil) & 38 & 45.78 & 103 & 75.18 & \\
\hline $\begin{array}{l}\text { Fazla kilolu (85.-97. } \\
\text { persentil) }\end{array}$ & 24 & 28.92 & 10 & 7.30 & \\
\hline Obez ( $>97$. persentil) & 8 & 9.64 & 5 & 3.65 & \\
\hline \multicolumn{6}{|l|}{ Bel/boy } \\
\hline Düşük $(<0.4)$ & 10 & 12.05 & 37 & 27.01 & \multirow{4}{*}{$0.005^{\prime}$} \\
\hline Normal (0.4-0.5) & 57 & 68.67 & 91 & 66.42 & \\
\hline Risk (0.5-0.6) & 13 & 15.66 & 8 & 5.84 & \\
\hline Yüksek risk ( $\geq 0.6$ ) & 3 & 3.61 & 1 & 0.73 & \\
\hline
\end{tabular}

Tüm öğrencilerin RTA ölçeğinden aldıkları puanların ortalaması ölçek genelinde $44.28 \pm 11.43$, ölçeğin gerginlik alt boyutunda $12.63 \pm 3.96$, bedensel belirtiler alt boyutunda $8.97 \pm 3.33$, endişe alt boyutunda $13.72 \pm 4.14$ ve sinavla ilgisiz düşünceler alt boyutunda $8.96 \pm 3.14$ şeklindedir (Tablo 3).

Tablo 3. Öğrencilerin cinsiyete göre Revize Edilmiş Sınav Kaygısı Ölçeği puan ortalamaları

\begin{tabular}{|c|c|c|c|c|c|}
\hline & Cinsiyet & S & $\overline{\mathbf{X}} \pm$ SS & Alt & Üst \\
\hline \multirow{3}{*}{ Gerginlik } & Erkek & 83 & $11.02 \pm 3.72$ & 5 & 20 \\
\hline & $\mathrm{K} ı \mathrm{z}$ & 142 & $13.57 \pm 3.81$ & 5 & 20 \\
\hline & Toplam & 225 & $12.63 \pm 3.96$ & 5 & 20 \\
\hline \multirow{3}{*}{ Bedensel belirtiler } & Erkek & 83 & $7.87 \pm 2.88$ & 5 & 18 \\
\hline & $\mathrm{K} ı \mathrm{z}$ & 142 & $9.62 \pm 3.42$ & 5 & 19 \\
\hline & Toplam & 225 & $8.97 \pm 3.33$ & 5 & 19 \\
\hline \multirow{3}{*}{ Endişe } & Erkek & 83 & $12.81 \pm 3.88$ & 6 & 22 \\
\hline & Kız & 142 & $14.26 \pm 4.20$ & 6 & 24 \\
\hline & Toplam & 225 & $13.72 \pm 4.14$ & 6 & 24 \\
\hline \multirow{3}{*}{ Sınavla ilgisiz düşünceler } & Erkek & 83 & $9.30 \pm 3.14$ & 4 & 16 \\
\hline & $\mathrm{K} ı \mathrm{z}$ & 142 & $8.76 \pm 3.13$ & 4 & 16 \\
\hline & Toplam & 225 & $8.96 \pm 3.14$ & 4 & 16 \\
\hline \multirow{3}{*}{ Sınav Kaygısı Ölçeği } & Erkek & 83 & $41.00 \pm 10.69$ & 20 & 68 \\
\hline & Kız & 142 & $46.21 \pm 11.45$ & 20 & 77 \\
\hline & Toplam & 225 & $44.28 \pm 11.43$ & 20 & 77 \\
\hline
\end{tabular}


Tablo 4. Öğrencilerin sosyo-demografik özelliklerine göre Revize Edilmiş Sınav Kaygısı Ölçeği puan ortalamalarının karşılaştırılması

\begin{tabular}{|c|c|c|c|c|c|}
\hline Sosyo-demografik özellikler & $\mathbf{S}$ & $\overline{\mathbf{X}} \pm \mathbf{S S}$ & Alt & Üst & $\mathbf{P}$ \\
\hline \multicolumn{6}{|l|}{ Cinsiyet } \\
\hline Erkek & 83 & $41.00 \pm 10.69$ & 20.00 & 68.00 & \multirow{2}{*}{$0.001^{* a}$} \\
\hline $\mathrm{K} 1 \mathrm{z}$ & 142 & $46.21 \pm 11.45$ & 20.00 & 77.00 & \\
\hline \multicolumn{6}{|l|}{ Yaş } \\
\hline 16 yaş & 21 & $43.57 \pm 12.79$ & 20.00 & 76.00 & \multirow{3}{*}{$0.434^{b}$} \\
\hline 17 yaş & 96 & $45.36 \pm 10.56$ & 25.00 & 75.00 & \\
\hline 18 yaş & 108 & $43.44 \pm 11.92$ & 20.00 & 77.00 & \\
\hline \multicolumn{6}{|l|}{ Öğrenim durumu } \\
\hline 11. Sinif & 49 & $43.24 \pm 11.95$ & 20.00 & 76.00 & \multirow{2}{*}{$0.396^{\mathrm{a}}$} \\
\hline 12. Sinif & 176 & $44.57 \pm 11.30$ & 20.00 & 77.00 & \\
\hline \multicolumn{6}{|l|}{ Eğitim görülen lise } \\
\hline Devlet lisesi & 172 & $44.30 \pm 10.98$ & 22.00 & 76.00 & \multirow{2}{*}{$0.821^{\mathrm{a}}$} \\
\hline Özel lise & 53 & $44.21 \pm 12.87$ & 20.00 & 77.00 & \\
\hline
\end{tabular}

${ }^{a}$ Mann-Whitney U testi, ${ }^{b}$ Kruskal-Wallis $H$, ${ }^{*} p<0.05$, S: Sayl, SS: Standart Sapma, $\bar{X}$ : Ortalama

Öğrencilerin cinsiyetlerine göre RTA ölçeği puan ortalamaları arasında istatistiksel açıdan anlamlı fark tespit edilmiştir $(\mathrm{p}<0.05)$. Erkek öğrencilerin RTA ölçeği puan ortalamaları (41.00ะ10.69), kız öğrencilere (46.21 \pm 11.45$)$ göre daha düşüktür. Çalışmadaki öğrencilerin yaş, öğrenim durumu, eğitim görülen lise, okul başarı durumu ve gelir durumuna göre RTA ölçeği puan ortalamaları arasındaki farkın istatistiksel olarak anlamlı olmadığı saptanmıştır ( $p>0.05$, Tablo 4).

Tablo 5. Öğrencilerin antropometrik ölçümleri ile Revize Edilmiş Sınav Kaygısı Ölçeği puanları arasındaki ilişki

\begin{tabular}{|c|c|c|c|c|}
\hline & & \multicolumn{3}{|c|}{$\begin{array}{c}\text { Revize Edilmiş Sınav } \\
\text { Kaygısı Ölçeği }\end{array}$} \\
\hline \multirow{3}{*}{ Vücut ağırlığı (kg) } & & Erkek & $\mathrm{K} ı \mathrm{z}$ & Toplam \\
\hline & $\mathrm{r}$ & -0.002 & -0.044 & -0.141 \\
\hline & $\mathrm{p}$ & 0.988 & 0.613 & $0.036^{*}$ \\
\hline \multirow{2}{*}{ Boy uzunluğu (cm) } & $\mathrm{r}$ & -0.097 & -0.043 & -0.201 \\
\hline & $\mathrm{p}$ & 0.383 & 0.618 & $0.003^{*}$ \\
\hline \multirow{2}{*}{ Bel çevresi (cm) } & $\mathrm{r}$ & 0.091 & -0.149 & -0.156 \\
\hline & $\mathrm{p}$ & 0.415 & 0.083 & $0.021^{*}$ \\
\hline \multirow{2}{*}{ Bel/Boy oranı } & $\mathrm{r}$ & 0.067 & -0.114 & -0.082 \\
\hline & $\mathrm{p}$ & 0.547 & 0.185 & 0.230 \\
\hline \multirow{2}{*}{ BKİ $\left(\mathrm{kg} / \mathrm{m}^{2}\right)$} & $\mathrm{r}$ & 0.043 & 0.003 & -0.013 \\
\hline & $\mathrm{p}$ & 0.698 & 0.970 & 0.852 \\
\hline
\end{tabular}

${ }^{*} p<0.05$
Öğrencilerin RTA ölçeği toplam puanları ile vücut ağırlı̆̆ı $(\mathrm{kg})$, bel çevresi $(\mathrm{cm})$ ve boy uzunluğu (cm) ölçümleri ile arasında istatistiksel açıdan anlamlı ve negatif yönlü korelasyon bulunmuştur $(p<0.05)$. Buna göre, öğrencilerin RTA ölçeği toplam puanları arttıkça vücut ağırlığı, bel çevresi ve boy uzunluğu azalmaktadır. Bel/boy oranı ve BKİ ölçümleri ile öğrencilerin RTA ölçeği puanları arasında korelasyon saptanmamıştır ( $p>0.05$, Tablo 5).

\section{TARTIŞMA}

Stres ve kaygı insan yaşamına çeşitli fizyolojik ve psikolojik boyutlarda etki edebilmektedir. Yüksek düzeylerde kaygı; şeker ve yağ oranı yüksek yiyeceklerin tüketiminin artması, iştahta artma veya azalma gibi beslenme durumlarında olumsuz etkilere neden olur. Sınav kaygisı; odaklanma, uyku güçlüğü, depresyon, düşük okul başarısı ile ilişkilendirilmiştir. Sınav kaygısı yaşayan öğrenciler yiyecekleri işlevsiz bir başa çıkma stratejisi olarak kullanabilir ve sağlıksız beslenme alışkanlıkları edinebilir. Bunun sonucunda öğrencilerde obezite gibi hastalıkların görülme riski de artmaktadır (15).

Adölesan dönemde kaygı düzeyi cinsiyet faktöründen etkilenmektedir. Llorca et al. (16) 417 adölesanın 
katılımıyla gerçekleştirdikleri çalışmada katılımcıları kaygı, saldırganlık, depresyon gibi yönlerden üç yıl süre ile incelemiş ve kızların bu dönem boyunca erkeklere oranla daha fazla kaygi belirtileri gösterdiklerini saptamıştır. Güler ve ark. (5) $245^{\prime} \mathrm{i}$ kız, 173’ü erkek olmak üzere toplam 418 lise son sinıf öğrencisinin sınav kaygısı düzeylerini araştırdıkları çalışmanın sonuçlarına göre kız öğrencilerin sınav kaygısı düzeylerinin erkek öğrencilerden anlamlı düzeyde yüksek olduğu bulunmuştur. Bu çalışmanın RTA ölçeği puan ortalamaları dikkate alındığında; kız öğrencilerin erkek öğrencilerden daha yüksek ortalamaya sahip olduğu ve ortalamaların arasındaki farkın istatistiksel olarak anlamlı olduğu saptanmıştır ( $\mathrm{p}<0.05$, Tablo 3). Toplumsal açıdan bakıldığında kız öğrencilerin duygularını açığa vurmasının erkek öğrencilerden daha kolay olması bu farklılığın sebeplerinden biri olabilir.

Üniversite sınavına hazırlanan 450 öğrenci üzerinde yapılan bir çalışmada öğrencilerin \%21.5’inin zayıf, \%60.0'ının normal ve \%23.5'inin fazla kilolu/obez olduğu gözlenmiştir. Erkek ve kız öğrenciler arasında boy uzunluğu, BKİ, bel çevresi ve bel/boy oranı açısından istatiksel olarak anlamlı farkların olduğu ve erkek öğrencilerin kız öğrencilere oranla daha yüksek değerlere sahip olduğu bulunmuştur (17). $\mathrm{Bu}$ çalışmanın sonuçları bu çalışma ile paraleldir. Erkek öğrencilerin anatomik özelliklerinin yanı sıra kızlardan daha yüksek antropometrik ölçüm değerlerine sahip olmasinın nedenlerinden birisi de kız öğrencilerin toplum tarafindan kabul edilen güzellik kriterlerinden biri olan zayıflık kaygısı sebebiyle kontrolsüz bir şekilde diyet yapması veya sağlıklı beslenme çabasında olmaları olabilir. Adölesan dönemde kız öğrencilerin dış görünüşlerine önem vermeleri erkek öğrencilere kıyasla daha yaygın görülmektedir. Bunun bir sonucu olarak kızlar kısıtlayıcı yeme davranışında bulunmaya daha eğilimlidir (18).

Kaygı bozuklukları ergenlikte yüksek bir prevalansa sahiptir ve önemli fizyolojik (nefes alma zorluklarl, ağız kuruluğu, taşikardi) ve psikolojik belirtileri (aşırı endişe, nedensiz korku, panik durumlar) vardır. Ayrıca adölesanların çevreleriyle ilişkileri ve akademik performansları üzerinde olumsuz bir etkisi vardır. Depresyon gibi olumsuz psikolojik durumlara ve agresif davranışlara da neden olabilmektedir (16). Türkiye'deki sinav sistemleri rekabete dayalı, haliyle stres ve kaygıyı tetikleyen bir düzendedir. Akademik stres, yani okulla ilgili olan ve akademik başarısızlık gibi durumlarla ilişkili stres, öğrencilerin başa çıkması gereken durumlar yaratır. $\mathrm{Bu}$ durumlarda kullanılan başa çıkma yöntemleri öğrencinin sınavlardaki başarısıyla doğrudan ilişkilidir (19,20). Sınav kaygısı ile başa çıkmaya çalışan öğrenciler bunun için farklı yollar izlerler. Yapılan bir çalışmada, 430 öğrencide sınav kaygısı ile başa çıkmak için kullanılan yöntemler sorgulanmış ve 354 farklı yanıt alınmıştır. Verilen yanıtlara göre müzik dinleme ve olumlu düşünmeye çalışma seçeneklerinden sonra en sık başvurulan başa çıkma yönteminin yemek yeme olduğu gözlemlenmiştir (21). Beslenme ile kurulan bu davranış şekli duygusal beslenme olarak adlandırılır (22). Bireylerin kaygılı zamanlarda yöneldiği yiyeceklerin daha çok yağlı ve şekerli besinler olduğu düşünüldügünde vücut ağırlığında artış beklenen bir sonuçtur. Fazla kilolu veya obez bireyler yalnızca kanser ve diyabet gibi hastalıklar açısından risk altında değillerdir. Vücut ağırlığı artışı aynı zamanda kaygı bozukluğu ve depresyon gibi ruhsal bozuklukların gelişimi ile de ilişkilidir (23). BKI ile kaygı bozukluğu arasındaki ilişkinin pozitif ve çift yönlü olduğu gösterilmiştir. İsveç’te yapılan geniş çaplı bir çalışmada, 6-17 yaş aralığındaki adölesanlarda obezitenin her iki cinsiyette de anksiyete ve depresyon için güçlü bir risk faktörü olduğu belirlenmiştir (24). Ancak genel beklentinin aksine kaygı ile BKİ arasındaki ilişki her zaman doğrusal ve pozitif yönde olmayabilir. Obez bireyi çevresel faktörlerin de önemli ölçüde etkilediği düşünüldüğünde, örneğin ailesi ve çevresinin de fazla kilolu veya obez olması, vücut ağırlığından daha az kaygı duyması da söz konusu olabilir (25).

Bu çalışmada öğrencilerin vücut ağırlığı, bel çevresi ölçümleri ile sınav kaygısı puanları arasında anlamlı ve negatif yönlü korelasyonlar saptanmıştır $(p<0.05$, 
Tablo 5). Bu durum sinava hazırlanma sürecinde hissedilen kaygının ve stresin besin alımını arttırmak yerine azaltan (hipofaji) bir etki göstermesinden kaynaklanıyor olabilir. Aynı zamanda bu dönemde öğrenciler artan uyku ihtiyacı ya da zamanın kısıtlı olması sebebiyle kahvaltı ögününü atlama gibi alışkanlıklar edindiğinden gün içinde yeterli beslenme sağlayamıyor olabilirler (26). Ancak bel/boy oranı ve BKİ değerleri ile sınav kaygısı puanları arasında korelasyon saptanmamıştır ( $p>0.05)$. Bu çalışma ile benzer olarak Gümüş ve ark. (9) üniversite sınavina hazırlanan 450 katılımcı ile gerçekleştirdikleri çalışmada; BKİ, bel çevresi ve bel/boy oranı ile kaygı puanları arasında önemli bir ilişki saptanmamıştır $(p>0.05)$.

Yüksek seviyede sınav kaygısı okul başarısını olumsuz yönde etkilemektedir. Sınav esnasında odaklanma sorunu, çok iyi bilinen bir konunun unutulması gibi durumlar öğrencinin potansiyelini gösterememesine neden olur. Sınav kaygısı yaşayan öğrenciler yaşamayan öğrencilere göre daha zayıf performans ortaya koyabilirler (6). Bu çalışmada, okul başarısı ile sınav kaygısı arasındaki ilişki istatistiksel olarak anlamlı görünmese de okulu doğrudan geçen öğrencilerle takdir alan öğrencilerin sinav kaygısı düzeyleri arasındaki fark göz ardı edilmemelidir. Buna göre; öğrencilerde başarı seviyesi arttıkça sınav kaygısı düzeyinde azalma gözlemlenmiştir. Köse ve ark. (27) tarafından yapılan bir çalışmada üniversite sınavına hazırlanan lise son sınıf öğrencilerinin en sık karşılaştığı engelin sınav kaygısı olduğu belirtilmiştir. Sınavlarda gösterilen performansın artması için öğrencilerin sınav kaygısı ile etkili bir şekilde başa çıkma stratejileri geliştirmeleri sağlanmalıdır.

Gelir durumu ile sınav kaygısı arasındaki ilişki incelendiğinde istatistiksel olarak anlamlı bir sonuç saptanmamıştır ( $p>0.05$, tabloda bulunmayan veri). Ancak gelir düzeyi azaldıkça öğrencilerin sınav kaygısı puanlarının arttığı görülmüştür. Bu çalışma ile benzer olarak lise son sınıf öğrenciler ile yapılan bir çalışmada, kaygı puanları ortalamalarının aile sosyo-ekonomik düzey değişkenine göre ilişkisi istatistiksel olarak anlamlı bulunmamıştır. Ancak orta sosyo-ekonomik düzeye sahip olan öğrencilerin kaygı düzeyleri, aileleri yüksek sosyo-ekonomik düzeye sahip öğrencilerden daha fazla olduğu gözlemlenmiştir (28). Üniversite sinavının öğrenciler için meslek seçimi ile toplumdaki statüsünü ve ekonomik olarak geleceğini belirleyebilecek bir sınav olduğu düşünüldügünde daha düşük gelirli ailelerin çocukları üzerindeki stres ve kaygı unsurlarının daha yüksek olması olasıdır.

$\mathrm{Bu}$ çalışmada üniversite sınavına hazırlanan öğrencilerin sınav kaygısı düzeyi ile bazı demografik özellikleri ve antropometrik ölçümleri arasındaki ilişki incelenmiştir. Çalışmanın sınırlılıklarından biri genellenebilirliğinin düşük olmasıdır. Çalışmanın örneklemini sadece Ankara ilindeki bir özel öğretim kurumunda eğitim gören gönüllü öğrenciler oluşturmaktadır. Bundan sonra yapılacak çalışmalara ülkenin farklı illerini kapsayan geniş bir örneklem grubu dâhil edilebilir. Ayrıca sınav kaygısı ölçeği ve antropometrik ölçümlerin eğitim-öğretim yllının başında, ortasında ve sonunda olacak şekilde üç defa uygulanması sonuçların detaylı analiz edilebilmesi için daha uygun olabilir.

Yazarlık katkısı - Author contributions: Çalışmanın Tasarımı: HÖ, PFT; Çalışma verilerinin elde edilmesi: HÖ; Verilerin analiz edilmesi; HÖ, PFT, Makale taslağının oluşturulmast: HÖ, İçerik için eleştirel gözden geçirme: PFT, Yayınlanacak versiyonun son onayl: HÖ, PFT $\square$ Study design: HÖ, PFT; Data collection: HÖ; Data analysis: HÖ, PFT; Draft preparation: HÖ; Critical review for content: PFT; Final approval of the version to be published: HÖ, PFT.

Etik Kurul Onayı - Ethics approval: Başkent Üniversitesi Tip ve Sağlık Bilimleri Araştırma Kurulu, 11/12/2019, 19/128.

Çıkar çatışması - Conflict of interest: Yazarlar çıkar çatışması olmadığını beyan ederler. $\square$ The authors declare that they have no conflict of interest.

\section{KAYNAKLAR}

1. Baysal A. Beslenme. 14. baskı. Ankara: Hatiboğlu Yayınlarl; 2012. 9-9.

2. Bull NL. Dietary habits, food consumption, and nutrient intake during adolescence. J Adolesc Health. 1992;13(5):384-8. 
3. Das JK, Salam RA, Thornburg KL, Prentice AM, Campisi S, Lassi ZS, et al. Nutrition in adolescents: Physiology, metabolism, and nutritional needs. Ann N Y Acad Sci. 2017;1393(1):21-12.

4. Jacka FN, Kremer PJ, Berk M, de Silva-Sanigorski AM, Moodie M, Leslie ER, et al. A prospective study of diet quality and mental health in adolescents. PLoS One. 2011;6(9):1-8.

5. Güler D, Çakır G. Lise son sınıf öğrencilerinin sınav kaygısını yordayan değişkenlerin incelenmesi. Türk Psikolojik Danışma ve Rehberlik Dergisi. 2013;4(39):8212.

6. Bhat RH. Emotional intelligence of adolescents in relation to their test anxiety and academic stress. Rehabilitation Sciences. 2017;2(1):21-5.

7. Beiter R, Nash R, McCrady M, Rhoades D, Linscomb M, Clarahan M, et al. The prevalence and correlates of depression, anxiety, and stress in a sample of college students. J Affect Disord. 2015;173:90-6.

8. Michels N, Man T, Vinck B, Verbeyst L. Dietary changes and its psychosocial moderators during the university examination period. Eur J Nutr. 2020;59(1):273-13.

9. Gümüş Bayındır A, Yardımcı H, Keser A. Sınava hazırlanan öğrencilerin beslenme durumlarının kaygı puanlarına göre değerlendirilmesi. DÜ Sağlık Bil Enst Derg 2018;8(1):22-6.

10. Lohman T, Roache A, Martorell R, editors. Anthropometric Standardization Reference Manual. Champaign, IL: Human Kinetics Books; 1991.

11. Ashwell M, Hsieh SD. Six reasons why the waist-toheight ratio is a rapid and effective global indicator for health risks of obesity and how its use could simplify international public health message on obesity. Int J Food Sci Nutr. 2005;56(5):303-7.

12. WHO. BMI for age (5-19 years). 2007. Available at: https:// www.who.int/tools/growth-reference-data-for-5to19years/indicators/bmi-for-age Accessed Dec 19, 2020.

13. Benson J, El-Zahhar N. Further refinement and validation of the Revised Test Anxiety Scale. Structural equation modeling: A Multidisciplinary Journal. 1994;1(3):203-18.

14. Akın A, Demirci İ, Arslan S. Revize edilmiş sınav kaygısı ölçeği: geçerlik ve güvenirlik çalışması. Eğitim Bilimleri ve Uygulama. 2012;11(21):103-18.

15. Caso D, Capasso M, Fabbricatore R, Conner M. Unhealthy eating and academic stress: The moderating effect of eating style and BMI. Health Psychol Open. 2020;7(2):115.
16. Llorca A, Malonda E, Samper P. Anxiety in adolescence. Can we prevent it? Med Oral Patol Oral Cir Bucal. 2017;22(1):e70-5.

17. Nur Aslan N, Yardımcı H, Özfer Özçelik A. Üniversite sinavina hazırlanan öğrencilerin makro besin ögesi alımları ve antropometrik ölçümlerle ilişkisi. Erciyes Üniversitesi Sağlık Bilimleri Fakültesi Dergisi. 2017;4(1):39-9.

18. Luo YJ, Niu G F, Kong FC, Chen H. Online interpersonal sexual objectification experiences and Chinese adolescent girls' intuitive eating: The role of broad conceptualization of beauty and body appreciation. Eat Behav. 2019;33(1):55-6.

19. Saffet Burak B. Ergenlerin mükemmeliyetçilik özellikleri ve akademik alanda arzuların ertelenmesi ile akademik stres arasındaki ilişkinin incelenmesi. Yüksek Lisans Tezi. İstanbul: İstanbul Sabahattin Zaim Üniversitesi Sosyal Bilimler Enstitüsü, 2016.

20. Çapulcuoğlu U, Gündüz B. Öğrenci tükenmişliğini yordamada stresle başa çıkma, sınav kaygısı, akademik yetkinlik ve anne-baba tutumları. Journal of Educational Sciences Research. 2013;3(1):201-18.

21. Şahin H, Günay T, Batı H. İzmir ili Bornova ilçesi lise son sınıf öğrencilerinde üniversiteye giriş sınavı kaygısı. STED. 2006;15(6):107-13.

22. Tribole E, Resch Elyse. Intuitive eating: A revolutionary program that works. St. Martin’s Griffin. 2003. 284 p.

23. Herhaus B, Kersting A, Brähler E, Petrowski K. Depression, anxiety and health status across different BMI classes: A representative study in Germany. J Affect Disord. 2020;276:45-7.

24. Lindberg L, Hagman E, Danielsson P, Marcus C, Persson M. Anxiety and depression in children and adolescents with obesity: A nationwide study in Sweden. BMC Medicine. 2020;18(1):1-9.

25. Haghighi M, Jahangard L, Ahmadpanah M, Bajoghli H, Holsboer-Trachsler E, Brand S. The relation between anxiety and BMI - Is it all in our curves? Psychiatry Res. 2015;235:49-5.

26. Story M, Neumark-Sztainer D, French S. Individual and environmental influences on adolescent eating behaviors. J Am Diet Assoc. 2002;102:40-11.

27. Köse S. The relationship between exam anxiety levels of senior high school students and sleep quality. J Psychiatr Nurs. 2018;9(2):105-11.

28. Kaçan Softa H, Ulaş Karaahmetoğlu G, Çabuk F. Lise son sinıf öğrencilerinin sinav kaygısı ve etkileyen faktörlerin incelenmesi. Kastamonu Eğitim Dergisi. 2015;23(4):1481-13. 